Canadian University Music Review

Revue de musique des universités canadiennes

\title{
Classical Music Criticism at the Globe and Mail: 1936-2000
}

\section{Colin Eatock}

Volume 24, numéro 2, 2004

URI : https://id.erudit.org/iderudit/1014580ar

DOI : https://doi.org/10.7202/1014580ar

Aller au sommaire du numéro

Éditeur(s)

Canadian University Music Society / Société de musique des universités canadiennes

ISSN

0710-0353 (imprimé)

2291-2436 (numérique)

Découvrir la revue

Citer cet article

Eatock, C. (2004). Classical Music Criticism at the Globe and Mail: 1936-2000. Canadian University Music Review / Revue de musique des universités

canadiennes, 24(2), 8-28. https://doi.org/10.7202/1014580ar
Résumé de l'article

Cet article étudie les développements de la critique musicale de la section de musique classique du journal Globe and Mail, de ses débuts en 1936 jusqu'à l'an 2000. On distingue trois périodes distinctes, en ce qui a trait au contenu, au style et à l'idéologie : 1936-1952, une période effervescente où les critiques considéraient de leur devoir de supporter les institutions musicales et les musiciens torontois; 1952-1987, époque où le journal a pris parti d'être plus détaché des musiciens et des activités musicales de la ville; 1987-2000, période où les critiques abordent les questions de nature sociale, politique et économique régissant la musique classique et remettent en question les $a$ priori culturels de l'œuvre d'art.
All Rights Reserved (C Canadian University Music Society / Société de musique des universités canadiennes, 2005
Ce document est protégé par la loi sur le droit d'auteur. L'utilisation des services d'Érudit (y compris la reproduction) est assujettie à sa politique d'utilisation que vous pouvez consulter en ligne.

https://apropos.erudit.org/fr/usagers/politique-dutilisation/ 


\title{
CLASSICAL MUSIC CRITICISM AT THE GLOBE AND MAIL: 1936-2000
}

\author{
Colin Eatock
}

The Globe [and Mail] was by reputation a "serious" newspaper, It had a power which outdistanced its mundane circulation figures. It conveyed the feeling that if only fourteen people across the country actually read the paper it would still be the most influential journal in Canada.

(Enright 1980, 101)

On November 23, 1936, a new newspaper appeared on the streets of Toronto called the Globe and Mail. Yet in one sense it was not new at all. From its first edition it laid claim to a prestigious, institutional status, as the amalgamation of two well established newspapers: the Globe, which was first published in 1844, and the Mail and Empire, which traced its corporate genealogy back to 1872. In a front-page editorial in the debut issue of the new journal, George McCullagh, President and Publisher, announced:

The task of uniting two of Canada's greatest newspapers, upholding the best in the traditions of each, and reconciling as far as possible their divergent policies involves a responsibility which I acknowledge fully ... I ask you to believe in my sincerity of purpose, in endeavoring to make the Globe and the Mail and Empire together a greater power for the public good than either could be separately, magnificent as have been their contributions under different conditions. (McCullagh 23 Nov 1936, 1)

At forty pages in length, the first Globe and Mail was the largest morning newspaper in Canada, and sixty-five tons of newsprint were required for its publication. From the beginning its emphasis was on national and international news: "Threats of War In Europe Grave," read one ominously prescient headline. But local news was also a priority for the essentially Torontonian Globe and Mail (it was to be forty-five years before it billed itself as "Canada's National Newspaper"), and it also offered extensive coverage of sports and business.

There was, however, no arts or entertainment section per se in the Globe and Mail of 1936; nor, on November 23, was there any classical music criticism. However, the following day's newspaper included two short music reviews, one cryptically signed "VND," and the other published anonymously. On November 27, the Globe and Mail's first clearly attributed classical music review appeared: a critique of the Kolisch Quartet by Lawrence Mason. Writing in flowery, 
rhetorical language, Mason offered the following description of the ensemble's performance of Ravel's Quartet in F:

The Ravel Quartet in F sparkled and glowed with jewelled radiance, proving utterly charming not only in the dulcet delicacy of elfin tone, but even more in the insight which gave the music exactly the degree of Watteau-like grace and artificiality which such fragile works demand. (Mason 27 Nov 1936, 18)

Mason, who contributed to the Globe and Mail until 1939, was the first in a long line of journalists who have written about classical music for the newspaper. Over the last seven decades these writers have run the gamut from knowledgeable professional musicians to amateur enthusiasts with little formal training in music, and the body of reviews and articles they have produced constitute a vast literature on the musical life of Toronto and Canada - too vast to be comprehensively examined on this occasion. Rather, the present goal is to construct a broad, chronological overview of music criticism at the Globe and Mail, in order to trace the development of discourse on classical music within the newspaper. This study is sub-divided into three eras: 1936 to 1952, 1952 to 1987 , and 1987 to 2000 - divisions that have ideological as well as chronological significance, and that parallel developments in the field of musicology.

\section{PART ONE: 1936 to 1952}

Although Mason's tenure at the new Globe and Mail was brief, he established a solid presence for music (which, in the 1930s, meant classical music) in the newspaper, regularly reviewing the Toronto Symphony Orchestra, international artists appearing at Massey Hall and Eaton Auditorium, and even local amateur performers. Born in Chicago in 1882-his grandfather had been mayor of the city during the Great Fire-he earned a Ph.D. in philosophy at Yale University and taught English literature there for seventeen years. He moved to Toronto and joined the staff of the Globe in 1924, writing Saturday columns and weekday reviews on both music and drama until his death at the age of fifty-four.

Mason's passing was considered by the Globe and Mail to be a significant loss both to itself and to the community, and he was honoured with a front-page obituary in which he was described as a writer "fearless in his criticisms [who] did not hesitate to express his opinions, whether favorable or unfavorable" ("Heart Attack" 11 Dec 1939, 1). Yet it appears that Mason also considered advocacy to be central to his role as a critic, and much of his writing seems driven by the spirit of boosterism: for Toronto and Canada, and also for the art of music itself." "He was a staunch supporter of the Toronto Symphony

1 Similarly, as a drama critic, Lawrence Mason has been credited with playing a significant role in the development of Canadian theatre. He has been described as "the first critic in English Canada whose overriding critical concern was to help to bring into existence a creative indigenous national theatre and drama." (Wagner http://www.canadiantheatre.com) 
Orchestra," said TSO conductor Sir Ernest MacMillan in Mason's obituary-and, indeed, his reviews of the orchestra, and of MacMillan, often overflowed with praise: on one occasion he stated in a TSO review that audiences "never need to fear that any musicians worthy of their salt will fail to recognize and fittingly respond to Sir Ernest's superb professional attainments and absolute musicianship" (Mason 22 Oct 1938, 11). ${ }^{2}$

In his promotional efforts, Mason went above and beyond the call of duty, contributing more than 130 Canadian entries to Thompson's International Cylopedia of Music and Musicians, and writing a series of articles on eighteen Canadian composers for the Globe in $1936 .{ }^{3}$ Such activities are consistent with the claim made by Mark N. Grant in his Masters of the Pen, that "American classical music critics were both tastemakers and activists" (Grant 1998, 337). However, in the context of Canadian music journalism, Mason's effort to canonize a group of Canadian composers stands out as unusual.

After Mason's death, the Globe and Mail appointed Hector Charlesworth as its music and drama critic in $1941 .{ }^{4}$ Born in Hamilton, Ontario, in 1872, he was a career journalist and broadcaster who had studied piano during his teens with the distinguished Toronto teacher Arthur Fisher. Until Charlesworth's passing in 1945, he wrote Saturday columns-filling them with reminiscences drawn from a rich vein of personal experience-as well as performance reviews during the week. Although his prose was less purple in hue than Mason's, he seemed even more reluctant than his predecessor to deliver an unfavourable verdict. Typical of his style during these years was his review of the TSO's season-opening concert of 1942, in which he observed that "the whole organization was in magnificent form, and Sir Ernest MacMillan's conducting was rich in energy and poetic fervor" (Charlesworth 28 Oct 1942, $25)$. Even when he felt it necessary to be less approving, his words were sugar coated, as in his review of a recital by the Canadian soprano Audrey Mildmay (the wife of Sir John Christie, the founder of England's Glyndebourne Festival Opera):

At her best her singing was a delight to the musically minded. At the outset her control seemed a little defective. There is a space between her upper and lower register, and the former is of much finer texture. The difference was noticeable in her first number, Handel's "As When the Dove," in which she was rather unsteady. Afterward, she grew in appeal. Her gift of piquant expression is notable, and her phrasing is marked by taste and delicate sentiment. (Charlesworth 4 Nov 1941, 8)

2 This concert also received favourable reviews from Toronto's other daily newspapers: the Toronto Daily Star (Bridle 28 Oct 1942, 33), and the Toronto Telegram (Wodson 28 Oct 1942, 25).

3 Ten columns entitled "Canadian Composers' Bibliographies" by Mason appeared in the Globe between May 30 and October 31, 1936. The eighteen featured composers were Alfred E. Whitehead, Sir Ernest MacMillan, Leo Smith, D.D. Slater, Allard de Ridder, W.O. Forsyth, Clifford Higgin, Luigi von Kunits, Arthur Collingwood, Thomas J. Crawford, W.H. Anderson, Alexander Chuhaldin, Gena Branscome, Charles O'Neill, Frank Blachford, R.B. Heyward, Frederic Lord and Edward W. Miller.

4The death or departure of a critic at the Globe and Mail has often been followed by a brief interregnum. In 1940, classical music was covered by Pearl McCarthy, Isabel Turnbull and Thelma Craig. 
The excerpt above shows that Charlesworth was not an undiscriminating listener. Yet he firmly embraced advocacy, much as his predecessor did-or possibly even more so, as, in a wartime context, concerts in Toronto were often viewed as morale-boosting events. (Certainly that was the argument Sir Ernest MacMillian put forward when the purpose of the TSO during the war years was questioned.) ${ }^{5}$ Possibly Charlesworth felt that any "negativism" at this time might be perceived as in poor taste, or even detrimental to Canada's war effort. Certainly, it is hard to imagine any Toronto critic daring to find fault with Sir Thomas Beecham's 1940 guest appearance leading the TSO, or with the orchestra's 1943 performance of Elgar's For the Fallen-to mention just two of many "patriotic" musical events from this era.

Like Mason, Charlesworth died while still professionally active, and he was eulogized in a Globe and Mail obituary, and in a statement from the TSO that underscored his close relationship with that organization:

The Toronto Symphony Orchestra is indebted to that Friend for encouragement and constructive criticism over a period of many years. "The men who are lifting the world upward and onward are those who encourage, more than criticize"-and Hector was one of those men. ${ }^{6}$

Once again the Globe and Mail found itself without a music critic, and for the next five years classical music was covered on an ad-hoc basis by several staff and freelance writers, including Anita Freedman, Helen Beattie, Allan Sangster and composer John Beckwith, who later became Dean of the University of Toronto's Faculty of Music. Most criticism in this era, however, was written by the husband-and-wife couple of Colin Sabiston and Pearl McCarthy.

Sabiston was born in Orangeville, north of Toronto, in 1893, and grew up in the Ontario town of Owen Sound, where he received "extensive private tuition in music and voice" ("Writer Long an Editor" 11 Sep 1961, 10). After serving in World War I he had a wide-ranging career, writing poetry, publishing a novel called Zoya, spending some time as a financial analyst, and contributing to Toronto newspapers such as the Telegram, the Daily Star, and the Mail and Empire. At the Globe and Mail he wrote about music and drama from 1946 to 1948 , retiring from the newspaper as an editor in 1959 and passing away in 1961. McCarthy was two years younger than Sabiston. The daughter of a Toronto insurance company president, she studied at the University of Toronto and at Oxford, where she earned a B.Litt. degree in 1927 ("Art Critic" 27 Mar 1964, 15). She also wrote for the Mail and Empire before its amalgamation with the Globe, and for the Globe and Mail from 1936 to 1964-principally as a visual art critic, but also covering music, drama and dance (not to mention fires and robberies). She worked to the end, penning her last article the day before 33).

5Sir Ernest MacMillan wrote: "People need music, and need it badly in wartime." (Warren 2002,

6The quoted phrase is attributable to the American educator Elizabeth Harrison ("Tribute to Critic" 23 Jan 1946, 9). 
she died. If her husband's musical training could be described as adequate to the task of music criticism, McCarthy's credentials as an art critic were exceptional: she had studied in Paris and knew Georges Braque personally. As well, she was sincerely interested in music, and in 1956 she published a monograph on the Toronto cellist, composer, teacher, author, and critic, Leo Smith.

Owing to the diversity of writers on classical music at the Globe and Mail between 1945 and 1950, it is difficult to summarize trends during this period. Sabiston and McCarthy shared forward-looking views on music and criticism: both were interested in Canadian composers-they wrote, often encouragingly, of John Weinzweig, Harry Somers, Barbara Pentland, Godfrey Ridout, Oskar Morawetz, Healey Willan, and others ${ }^{7}$-and both took a more detached and critical view of music and musicians than had Globe and Mail journalists before World War II. Toronto's musical culture was changing, with new performers and composers on the scene, and the Sabiston-McCarthy "team" strove to keep pace with developments. Sabiston, in 1948, observed:

The difference between the routine of a week's music in Toronto of the current season and a very few seasons ago is so great that to have gone through the transition is like having experience of another world.

It is true that celebrities still bring us a great deal of fine music-Kreisler bringing us warmth of heart, Pinza superlative excellence of performancewith others of a more ordiniary calibre filling in; but what is unique is the manner in which Canadian performers and composers are winning audiences for their music. (Sabiston 14 Feb 1948, 8)

In his Saturday columns, Sabiston sometimes adopted a clinically analytical tone: "Widespread, varied and often excellent choral activity in evidence in Toronto provides one of the soundest indices for measuring the vitality of music in the city," he postulated in one article (Sabiston 3 Apr 1948, 10). McCarthy, while maintaining a generally supportive stance towards music and musicians, carefully dissected the performances she reviewed. Her praise was sometimes tempered with reservation: soprano Marian Anderson was "great in voice," but she "let her deep respect of composers such as Handel cast a very tense, severe mood over the music" (McCarthy 2 Apr 1948, 8); and while tenor

7McCarthy often approved of new Canadian works. Reviewing a 1945 concert consisting of (unnamed) string quartets by Harry Somers and Oskar Morawetz, and songs for soprano and oboe by Godfrey Ridout, she wrote: “ ... their accomplishments proved that [there] was indeed native material worth the anxiety of those who work to make it known" (McCarthy 29 Jan 1945, 22). And concerning the opera Deirdre, by Toronto composer Healey Willan, she observed, "It is decidedly thrilling music, with an important role for the orchestra, which, under Ettore Mazzoleni, has done praiseworthy work" (McCarthy 20 April 1946, 9). Sabiston, while clearly interested in contemporary Canadian music, admitted that he did not always understand what he heard. Reviewing a 1948 vocal-piano recital Kenneth Peacock's Suite, Harry Somers' Testament of Youth, Barbara Pentland's Studies in Line and Ivan Gillis' Sonata, he wrote: "It is easy enough to see what Gillis was driving at in his Sonata ... But it is often not so simple a matter to determine what some of the other young Canadian composers are trying to express" (Sabiston 14 Feb 1948, 8). 
Torsten Ralf"s vocal technique was a "miracle of production," his program was "not consistently good" (McCarthy 17 Oct 1947, 26). There was even a rare element of sarcasm in one of her TSO reviews:

\begin{abstract}
Toronto players have plenty of ability and the appeal of the orchestra's performances seems to vary with their will to excel. Since there was much delight in three movements from Holst's Planets, and as the playing of the Mozart Kleine Nachtmusik just occasionally sounded as if they thought they were playing for the Changing of the Guard instead of a serenade, one may conclude that Mozart's light music is not considered worth too much concentration and subtlety. That is debatable. (McCarthy 20 Feb 1946, 19)
\end{abstract}

According to McCarthy the TSO, under MacMillan, was quite capable of giving an indifferent performance-despite Mason's assertion, eight years earlier, that such a thing was inconceivable.

The modern "features" article also appeared in the post-war years. While advance stories about forthcoming events in Toronto had always been a staple of arts writing at the Globe and Mail, before World War II such articles were almost invariably "puff pieces," highlighting a visiting artist's talents and accomplishments. Critical assessments of musicians, as well as discussions of programming, finances, and other behind-the-scenes issues were rare, but after 1945 such articles began to emerge. A feature article by Eva-Lis Wuorio on Toronto's Proms Concerts stands out as an early example of a kind of journalism (now common) that attempts to offer an inside view of the arts world, by explaining how the concerts' expenses and logistics were arranged (Wuorio 22 May 1946, 15). As well, a few critics in this era began to deviate from the tradition of writing in the third person ("this writer"), or with the "royal we," or of avoiding self-reference altogether, and began to use the pronoun "I." 8 This subtle shift in discourse emphasized the subjectivity of criticism-positioning the critics' views as entirely their own, rather than official pronunciamenti of the Globe and Mail.

Sabiston stopped writing about music and drama in 1948, to become an editorial writer at the Globe and Mail. His wife continued to write about music - in addition to her other duties - but by 1950 the newspaper's editors decided that a full-time classical music critic was needed. According to McCarthy it was her husband's idea to offer this position to Leo Smith (McCarthy 1956, 43). Smith (already mentioned here as the subject of McCarthy's 1956 monograph) accepted the job, and thereby became the most accomplished musician ever to hold the position of music critic at the Globe and Mail.

Originally from Birmingham, England, where he was born in 1881, Smith was a prodigious cellist who went on to play in the Hallé and Covent Garden

8Sabiston used the first person in a 1948 review of Thomas L. Thomas; however, the earliest example of criticism in the first person may be Allan Sangster's review of pianist Mariann Grudeff (Sangster 13 May 1946, 21). 
orchestras. McCarthy speculated that he immigrated to Canada because he "loved being part of new developments" (McCarthy 1956, 12). Arriving in Toronto in 1910, he served as the TSO's principal cellist and taught at the Toronto Conservatory of Music until his retirement from that institution in 1950 at the age of sixty-eight. Evidently the Globe and Mail considered his engagement a coup, and his ascent to the position of music critic-he wrote on no other subject-was announced in a prominent column that catalogued his many talents ("Leo Smith" 9 Sep 1950, 8).

In a striking departure from journalistic practices, Smith's earliest Saturday columns resembled professorial lectures: Globe and Mail subscribers may have been surprised to read that "the sixteenth century saw the emancipation of instrumental music from vocal styles" (Smith 16 Sep 1950, 8); or that the Greek philosopher Aristonexus defined music as "a sense (auditory) discrimination of sound requiring hearing and intellect" (Smith 9 Sep 1950, 8). When discussing more current matters, Smith would often examine a problem from all points of view, while coyly withholding any judgements of his own. For instance, in an essay on the merits of government funding for the arts-an idea that was then entering Canada's political consciousness-he began by mentioning some countries that supported the concept of state funding, followed by a list of several that did not. He continued:

As to the pros and cons of these points of view of the general question of state subsidy against private support, I can speak only briefly. Both can point to a lengthy list of success; both can be assailed with opposing argument. Nevertheless, one economic consideration is apparent. No art can prosper which has only scanty and uncertain opportunity of employment. (Smith 4 Nov 1950, 8)

While Smith makes the point that the money must come from somewhere, any personal opinions he might have held about public versus private support for music are conspicuously absent.

Smith's penchant for "balanced" commentary also permeated his concert reviews. Responding to a performance of La Traviata by the touring Rosselino Opera Company, he offered this ambivalent view of the prima donna:

... I felt that Violetta, in particular, occasionally failed to hear the orchestra sufficiently well, with the result that her intonation was at fault. Still, Traviata is a difficult role requiring a fine vocal technique. And, as I have said, there were fine and effective moments besides a genuine pleasure to the eye. (Smith 2 Oct 1950, 28)

And in his review of the TSO's 1950 performance of Bartók's Concerto for Orchestra, Smith was eloquently equivocal:

... the melodic idiom, the harmony, the chain of musical reasoning, the complex texture more often than not seem to defy our previous experience. Consequently, it is natural that the average listener should become bewil- 
dered. He fails to catch the music's infection and he asks: To what issue? Why tax the fingers for such a mountain of labour?

On the other hand it has to be admitted that Bartók disciples are many, and that they include distinguished writers and critics of today. To them the composer is linked with the two-faced Janus-the Roman God and the patron of new enterprise. Bartók, they say, is the gateway through which music must travel if it is to be revitalized with new idioms and new thought.

Listening to the work last night I found myself struggling with these conflicting opinions. At times I was absorbed with the cleverness of it all. The surging waves of sound, the mysterious shadow tints, the changing rhythms, the curious drone-like chord-supports appearing often to have no harmonic connection with what was going on above yet sounding strangely satisfying, the unusual cadences, the bits of lovely colour, particularly in the flute and clarinet. I could admire the consistency and the originality which shows its impress in every page.

Against this, however, it must be admitted that the music is hard and adamant. Only for a few fleeting moments in the fourth movement does the composer yield a little to simpler euphony. And surely it is unnecessarily difficult. The violins for instance scale to dizzying heights. That twenty or more should execute some daring gyrations in such altitudes without some discrepancy in pitch seemed to me to be possible only by the Grace of God. (Smith 1 Feb $1950,8)$

If Smith ever reached any conclusions about the merits of the Concerto for Orchestra-beyond noting that it is hard to play-they will forever remain a mystery. ${ }^{9}$

In some ways Smith's writing was a throwback to pre-World War II politesse; in other respects, it looked forward to the end of the twentieth century, when arts columns in the Globe and Mail sometimes assumed lofty and theoretical tone; and in its non-judgmental stance it was unique. His tenure at the newspaper was short: he passed away in 1952. Although he was the least opinionated music critic ever to write for the Globe and Mail, his obituary declared that "a lifetime career in music gave his writings authority which other criticisms often lacked" ("Composer and Teacher" 19 Apr 1952, 16).

Smith's passing was also noted by a newspaper in a small city northeast of Toronto. In an unsigned editorial in the Peterborough Examiner-probably written by the novelist Robertson Davies, who was the newspaper's editor at the

9McCarthy, in her biographical monograph, approvingly cited this review as "a prime example of setting forth both sides of a case." Defending Smith's unusual style of criticism, she wrote: "If a critic works on the basis of personal taste, he lacks integrity as a critic" (McCarthy 1956, 44-46). This view of criticism is similar to an opinion expressed by the composer and New York Herald-Tribune critic Virgil Thomson. "Any music critic or book critic who sets out to champion things is an idiot ... Nobody's interested in what you think about something or feel about something. They want to know what took place, when and where, and what it was like" (Grant 1998, 253). 
time-all three of the Globe and Mail's past music critics were recalled. The Globe and Mail reprinted the editorial:

The late Lawrence Mason's articles, and his Saturday page, were widely appreciated. Hector Charlesworth, following him, dealt with music not so much from a technical as from a personal point of view ... Leo Smith, more technical in his approach was less genial, but more scholarly and no less admirable. ("Globe's Music Critics" 26 April 1952, 8)

This editorial was, in effect, an obituary for an era: music criticism at the Globe and Mail would never be the same again.

\section{PART TWO: 1952 to 1987}

In the winter of 1952, Smith, then ailing, asked a young man working at the newspaper to write some concert reviews. According to journalist and author Richard J. Doyle, "Smith turned with increasing frequency to John Kraglund, a young, willing, and industrious clerk in the Globe and Mail library. He filled in where he was needed, a pupil, if not a protégé of the old professor" (Doyle 1990, 89). Doyle continues:

When Smith died at seventy, [Editor-in-Chief Oakley] Dalgleish scanned the usual places for an illustrious successor. But the thought persisted that he should give Kraglund a chance. "What the hell?" he explained. "He knows a good deal about the subject, he's eager as you could want, and he's helped us out when we needed him. Of course, he can't write worth a damn but we can fix that. Teach him."

Kraglund was born in Denmark in 1922, and immigrated with his family to Ontario's Prince Edward County in 1929. He earned a Bachelor of Arts degree in the liberal arts from the University of Toronto in 1948-the University College yearbook lists his interests as "music and theatre"-and he joined the staff of the Globe and Mail shortly after graduation. The extent of his formal musical education remains unclear: the Encyclopedia of Music in Canada states only that, "he studied theory and criticism with Leo Smith" (Cowle 1981, 506). But even if there were gaps in his musical education, he cultivated a strong interest in the subject. ${ }^{10}$ Unlike most of his predecessors, who were older men, already established in Toronto's cultural community when they became critics, Kraglund was only thirty years old and virtually unknown. There was no formal announcement of his appointment as music critic, yet he held this position for thirty-five years-and while many other writers contributed articles on classical music to the Globe and Mail during this period, his reviews were the cornerstone of classical music coverage. Kraglund was prolific: his

10According to Beckwith, Kraglund owned a substantial record collection (Beckwith interview 2004). Similarly, broadcaster Kenneth Winters remembers that Kraglund owned a piano, although he does not recall ever hearing him play it. Observes Winters, "He was a very good listener, and-a very experienced listener. He learned on the job-he had a gift for it" (Winters interview 2004). 
columns number in the thousands, and through them he commented upon a time of growth for classical music in Toronto. ${ }^{11}$

Once Kraglund was installed at the Globe and Mail, music criticism at the newspaper changed noticeably: the young critic, although a protégé of Smith, clearly did not share his mentor's approach to reviewing. According to the Encyclopedia of Music in Canada, Kraglund's "drily sardonic, usually brief reviews, pragmatic in the face of a midnight deadline, became a hallmark of Toronto scepticism," adding, "a measured enthusiasm from Kraglund was the equivalent to a panegyric from a colleague" (Cowle 1981, 506). Initially, he restored the use of the "royal we" and the indirect "this-reviewer" style of the pre-war years. Also a 1953 review of soprano Margaret Truman (the daughter of American president Harry Truman) illustrates a feature commonly found in his writing: his tendency to offer a compliment with one hand and retract it with the other.

There are possibilities for Miss Truman's middle vocal register as shown in the gay little French art song, "Le Coeur de ma Mie" by Dalcroze. But even here most credit is due to her gamin-like personality. Clear diction marked her performance of three British folk songs. There was a simplicity of presentation that made "No, No, John" pleasant listening. However, in the interests of good reporting it must be admitted that the spontaneous burst of applause for "I Know Where I'm Goin"” was precipitated by Miss Truman's winsome shrug —after she had finished the selection. (Kraglund 30 Oct 1953, 30)

Kraglund concluded in words that left no doubt as to his opinion:

In short, Miss Truman did not persuade this reviewer that she could sing. Her voice lacks warmth and richness. Intonation was rarely accurate, and the general lack of control made coloratura passages anything but decorative. The total result was unfortunate.

Kraglund was first and foremost a critic, in the strictest journalistic sense of the term, and was concerned primarily with describing and evaluating musical performances. He rarely wrote sweeping "opinion pieces"-but neither did he ignore the issues of his era. Rather, he discussed them in piece-meal fashion, one column at a time, and a broad survey of his writing reveals much about his views on major developments. Two of these developments will be examined in detail here, partly because of their prominence in Toronto's musical life, but also for what they reveal about Kraglund: the emergence of the Canadian Opera Company in the 1950s, and the remarkable career of Glenn Gould in the 1960s.

Before 1950, opera production had a chequered history in Toronto. Various local amateur and semi-professional companies rose and fell, while the city

11 Curiously, neither Kraglund nor Smith wrote about the "Symphony Six" scandal of 1952 that rocked the Toronto Symphony Orchestra and led to the dismissal of half a dozen players. At the time these events unfolded, Smith was unwell and Kraglund had only just been begun to write about music. Perhaps neither felt up to the task of commenting on such a controversial subject. 
relied on productions from New York's Metropolitan Opera and other touring companies for fully professional performances. But in 1946 the Royal Conservatory of Music set out to change this by establishing a homegrown, ultimately professional, opera company in Toronto. In 1950 an opera festival was launched, first under the name of the Royal Conservatory Opera Company, later as the Toronto Opera Festival Association, and finally, in 1958, as the Canadian Opera Company. The Globe and Mail allied itself closely with this venture: during the 1950s the newspaper gave Toronto's annual opera festival generous coverage in its arts and society pages. Feature articles and plot synopses, usually written by Kraglund, were published just before opening night, as were publicity photos of cast members. Sometimes Kraglund and theatre critic Herbert Whittaker both attended performances, with their critiques appearing side-by-side in the next day's newspaper: Kraglund's review focussing on the musical performance, and Whittaker's review concerned with the theatrical aspects of the production.

While the Globe and Mail generally portrayed the fledgling opera company as a grand and glamorous affair, Kraglund, in his reviews, took a non-partisan stance. He no doubt favoured the establishment of a professional opera company in Toronto in principle, but this did not mean that everything it did was worthy of praise. He remarked that a performance by soprano Teresa Stratas was merely "acceptable," and that director Herman Geiger-Torel's staging suffered from "light moments which are not very light" (Kraglund 24 Oct 1957, 8). In 1955 he found fault with an entire opera season before it began. "We have been disappointed by the Festival's choice of operatic fare for the next season-Puccini's Madama Butterfly, Mozart's Don Giovanni and Bizet's Carmen," he complained, urging the company to explore less frequently heard repertoire (Kraglund 18 Jun 1955, 10).

By insisting upon a distinction between opera as an ideal and operas as they were performed, Kraglund established the kind of detached, critical position vis-à-vis opera in Toronto that Mason, Charlesworth and Smith did not maintain towards the TSO. Kraglund rejected the notion that it was his duty to foster Toronto's musical institutions, but he was not indifferent to the growth of opera in the city: commenting favourably on the festival in 1958 he wrote: "what has been developed culturally is nothing short of miraculous" (Kraglund 11 Oct 1958, 15).

Another prominent event during Kraglund's lengthy tenure was the meteoric rise and unique career of the pianist Glenn Gould. This phenomenon began before Kraglund's time, in the late 1940s, when the teenaged prodigy first came to the public's attention. "Glenn Gould, fifteen, gave a piano recital at Eaton Auditorium last night which should qualify him for a place among ranking adult artists," reported Sabiston in 1947 (Sabiston 21 Oct 1947, 10). Kraglund first reviewed Gould in 1953, and was impressed: "Glenn Gould gave evidence yesterday afternoon at Eaton Auditorium that Canadian pianists can take their place among the top artists generally heard here" (Kraglund 20 Nov 1953, 12). 
Gould's steps to international stardom in the mid-1950s-his recitals in Washington and New York in 1955, his debut with the New York Philharmonic in 1957, and his tour to Russia later that year-were closely followed by the Globe and Mail. By the last years of the decade, Gould's name appeared with almost weekly regularity in the newspaper: everything he did, or was about to do, or decided not to do (he frequently cancelled concerts) was duly reported. Kraglund, at first, declared himself one of Gould's admirers.

In 1954, he wrote:

When Toronto pianist Glenn Gould gives a recital the audience is assured a brilliant performance of a number of technically difficult, and so infrequently heard, compositions. (Kraglund 26 Oct 1954, 27)

Reviewing a recital of Bach's Goldberg Variations the following year, Kraglund was (momentarily) effusive-while also noting some of Gould's singular characteristics:

The pianist became the mystic poet. No longer were we embarrassed by stage mannerisms, frequently labelled distracting, for we, like him, became a part of the music. Nor did it matter that this interpretation did not agree entirely with others we have heard. (Kraglund 30 Jun 1955, 10)

But towards the end of the decade the critic began to have doubts about Gould. In 1958 he cautioned readers that a new Gould recording of Mozart and Haydn was "likely to cause a measure of controversy" (Kraglund 30 Aug 1958, 13). While praising it as "notable for clarity and precision," he added that the Mozart contained "less grace and charm than we should have liked," and the Haydn suffered from "mechanical execution." One year later he criticized Gould indirectly, in a review of Anahid Alexanian, an unknown, seventeenyear-old pianist. He claimed that her performance showed "too much of the Glenn Gould influence" (Kraglund 10 Jan 1959, 13).

On stage and off, Gould's eccentricities seemed to be multiplying. In London in 1959 he gave interviews in his overcoat and gloves, abruptly cut short a rehearsal with the London Symphony Orchestra, and then cancelled his LSO debut, citing ill health. In the spring of 1960 he withdrew from all his engagements and filed a lawsuit against Steinway and Sons for $\$ 300,000$, claiming that a Steinway employee had injured him with a friendly slap on the back. All this appeared in the Globe and Mail-and Kraglund, in his reviews, expressed disapproval with various facets of Gould's artistic development.

Gould had begun to compose and, in a 1961 review of his String Quartet No. 1, Kraglund suggested that "its appeal would be increased greatly if the composer had said all he had to say in eighteen, instead of thirty-five minutes" (Kraglund 25 Mar 1961, 13). Later that year he took Gould to task for his efforts as a chamber musician:

Mr. Gould's greatness as a solo performer is undisputed. I must confess I am less enthusiastic about him as an ensemble player, for he tends to dominate 
the performance without full consideration for the composer or the other performers. (Kraglund 17 Jul 1961, 11)

Attacks on Gould's recordings soon followed: his Brahms was "limp and sentimental" (Kraglund 9 Sep 1961, 13); and his Beethoven was faulted for "wayward, often too slow tempos" (Kraglund 14 Nov 1961, 15). And when Gould appeared on CBC television program intended to introduce young people to classical music, Kraglund made clear his opinion that the pianist's career was out of control.

I would not suggest that Mr. Gould set up business as a musicologist. For one thing, there are enough of these and too few great pianists. For another, while we can allow his frequent differing with generally accepted opinions, it is difficult to keep up with his rapidly changing enthusiasms and artistic focus. (Kraglund 14 Nov 1961, 15)

The gloves were off. When Gould devised and presented a music-theatre piece called Panorama of Music of the Twenties at the Stratford Festival in 1962, Kraglund scoffed:

Now that pianist Glenn Gould has proved conclusively - to himself, one hopes, and surely to an audience of 1,500 persons-that it will be a long time before he becomes a successful stage director, perhaps he will return to music. (Kraglund 15 Jan 1962, 44)

The performance, said Kraglund, portrayed the 1920s as "a time of unmitigated boredom," and Gould's attempts at humour were "about as light and frothy as a tub of wet cement." Although Kraglund continued to acknowledge Gould's pianistic mastery, he mercilessly attacked every new venture: his television appearances, his lectures, and his interest in the harpsichord.

In 1964 Glenn Gould famously withdrew from the concert stage to devote himself exclusively to the recording studio. This, to Kraglund, was the crowning folly of Gould's career, and in 1966 he alluded to the decision with characteristic sarcasm:

Listeners who still remember Toronto pianist Glenn Gould will be pleased to know that he occasionally emerges from his gold-plated garret to continue his recording of the complete solo keyboard works of Bach, Beethoven and Mozart. (Kraglund 6 Dec 1962, 44)

Later that year, Kraglund devoted an entire column to Gould's decision.

... Toronto pianist Glenn Gould seems to be convinced that if he repeats the words, "concerts are out, recordings are in," frequently enough he will make it so. Judging by the reactions of the public, and those of his fellow recording artists who are still concert performers, Gould's theory is rapidly gaining no support whatsoever. (Kraglund 26 Nov 1966, 17) 
Kraglund offered his own "middle-ground" position-and called into question Gould's motives for abandoning the concert stage:

Live concerts provide an emotional experience recordings usually do not offer. On the other hand, recordings permit closer acquaintance with the music's detail and an opportunity to hear works that are seldom performed in concerts of performances for monetary, among other reasons, as Gould himself pointed out. Whether Gould has plotted his small crusade against concerts out of deep conviction or because it serves as one of his small tokens of non-conformity, only he knows.

Although Kraglund ended this article on a conciliatory note-proposing that if Gould continued to work in the studio and other artists continued to concertize, listeners would have "the best of both worlds"-it was clear that Kraglund had little sympathy for Gould's views. In later years Kraglund continued to review Gould's recordings, often favourably, and when the pianist died in 1982, the critic wrote a respectful, full-page obituary (Kraglund 5 Oct 1982, 13). But beyond these gestures Kraglund treated Gould almost as though he had ceased to exist.

What does the relationship between Kraglund and Gould tell us about the critic? First and foremost, he was not a man to establish and cling to loyalties, and was quite willing to change his mind about an artist when he felt so inclined. As well, Kraglund's discussion of Gould underscored Kraglund's detachment from the musical world he wrote about. Whereas some of the Globe and Mail's previous critics had maintained professional and even personal connections to the musicians they discussed, Kraglund stood apart. He never directly interviewed Gould, preferring to offer comment only on his performances, recordings and public statements. Finally, Kraglund's conservative, crystallized views of classical music may have led him to focus too much on the question of whether Gould was "right" or "wrong." The notion that Gould's unusual and often iconoclastic views could be of greater value to the world than the conventional correctness of a thousand lesser artists may not have occurred to him.

Kraglund wore his conservatism as a badge of honour: for him the standard concert format and the canonic repertoire were immutable traditions. In this regard he "ratified existing taste"- to use the same phrase that the essayist Samuel Lipman used to describe Harold C. Schonberg, whose tenure as classical music critic of the New York Times coincided roughly with Kraglund's at the Globe and Mail (Lipman 1984, 226). Kraglund was often hostile towards modernist and avant-garde composers, and when reviewing the Toronto contemporary-music producer New Music Concerts in 1978, he was ironically dismissive of the organization's efforts:

An aim of New Music Concerts is to promote contemporary music and to foster an interest in it ... Perhaps future series should include one or two programs featuring the replay of music not generally considered an absolute waste of time. (Kraglund 13 Mar 1978, 14) 
The rise of the early music movement-another significant development in Kraglund's years-also aroused his suspicion of novelty. At first he did not take Toronto's Tafelmusik Baroque Orchestra, founded in 1979, seriously: he gently mocked the performers for their earnestness; and often sent a freelance writer to review the group's concerts in his stead. However, unlike his ongoing hostility towards much new music, Kraglund's attitude towards Tafelmusik gradually changed. In 1984 he wrote:

It sometimes seems as if Tafelmusik, Canada's Baroque orchestra, has been around forever, yet it only celebrated its fifth anniversary last season, which makes it an infant compared to most of Toronto's other ensembles that present annual concert seasons ...

Most of its supporters will have no difficulty recalling the questionable calibre of early performances, so the strides made in the past couple of seasons seem gigantic. How many other musical five-year-olds have won approval across Canada and the United States? (Kraglund 14 Jul 1984, E12)

Kraglund's conservative stance rendered his reviews easily distinguishable from those of his more open-minded colleague at the Toronto Star, William Littler. Indulgent towards New Music Concerts, enthusiastic about Tafelmusik, and favourably disposed towards most other music presenters in Toronto, Littler became known for a light, breezy style. Kraglund, by comparison, could be blunt and acerbic: he offended some readers, and irate letters concerning his reviews appeared from time to time in the Globe and Mail. One 1960 review of the Toronto Mendelssohn Choir provoked a flurry of indignant responses, including:

Mr. John Kraglund's music criticisms, in my opinion, contribute nothing to the cultural life of our city; they may even have a detrimental effect, if those who are responsible for contributing to our musical life pay any serious attention to his discouraging critical efforts. (Mary L. Campbell 7 Dec 1960, 6)

Also:

I am disgusted with your music critic, Mr. John Kraglund. Apparently the professional musicians pay no attention to his criticism, but he pans so many worthwhile performances that young people who might become interested in these good things are completely discouraged. (Ruby G. Allen 7 Dec 1960,6)

And, finally:

Many of my friends and I are frequently annoyed by the carping tone of your music criticisms, but never have I been more so than after reading the account of the performance by the Mendelssohn Choir and the Toronto Symphony Orchestra of Carl Orff's Carmina Burana. (Harriet Rouillard 7 Dec 1960,6) 
By 1987 his years of writing reviews almost every night for the next day's newspaper began to take their toll. At the age of sixty-five he retired to a farm in Eastern Ontario-and stopped writing about music altogether. "I think the enthusiasm had gone out of it," suggested his friend, the broadcaster and writer Kenneth Winters. "At the time he retired he had been at it for a long time" (Winters interview 2004). While his own style of criticism changed little over thirty-five years, arts journalism at the Globe and Mail underwent a gradual metamorphosis: coverage was expanded across the country through a network of regional staff and freelance reporters; feature articles grew in number and prominence; and reviews of amateur ensembles appeared less frequently. ${ }^{12}$ As well, the Kraglund era saw an enormous growth in the criticism of popular music at the newspaper.

\section{PART THREE: 1987 TO 2000}

Kraglund's decision to retire at the age of sixty-five made it possible for the Globe and Mail to plan a smooth transition, and Robert Everett-Green-a writer who had already contributed articles on various subjects to the newspaper-was appointed as music critic. Born in Edmonton in 1956, Everett-Green had studied oboe at Boston's New England Conservatory of Music before moving to Toronto in the mid-1980s. After Kraglund's retirement, it soon became apparent that the younger critic's approach was markedly different from that of his older colleague. ${ }^{13}$

While Everett-Green's judgements could at times be as scathing as Kraglund's, at other times they were more generous in their praise. And whereas Kraglund's critiques were essentially limited to descriptions of performances and his own reactions to them, Everett-Green took a broader approach-certainly indicating his subjective response, but also delving into the issues behind the events he wrote about. Thus, a 1987 review of a concert by pianist Louis-Philippe Pelletier served as an occasion to discuss recital programming in general (Everett-Green 26 Mar 1987, E14); and a 1988 review of a recording of Beethoven's Symphony No. 9 by the London Classical Players offered an opportunity to write about the early music movement's incursions into the nineteenth century (Everett-Green 8 Feb 1988, E3). Also, when the Vancouver Symphony Orchestra went bankrupt in 1990, Everett-Green examined its financial problems but also questioned the changing role of orchestras in North American society, quoting Ernest Fleischmann, the general manager of the Los Angeles Philharmonic:

Mr. Fleischmann bluntly states that the symphony orchestra in its present form is dead, the victim of its own stagnant routine. In its place, he advocates a

12Today, the policy of excluding reviews of amateur performances from the Globe and Mail is overlooked only for the student productions of the University of Toronto's Opera Division, which are still routinely covered.

13Robert Everett-Green recalled: "I can't say that I knew John Kraglund very well-he was a personally reserved person. He was not a mentor” (Everett-Green interview 2004). 
multi-functional "community of musicians" that would absorb the most vital activities of traditional orchestras, chamber music societies, period-performance groups and contemporary music collectives. (Everett-Green $20 \mathrm{Feb}$ $1988, \mathrm{D} 2)$

In 1990 Everett-Green defined his own critical priorities in a feature article, setting forth his values and interests. At the top of his list was new music.

In theatre, this would seem self-evident, but it is not so among the "classical" establishment, nor among many who write criticism. The classical establishment today is perverse, in that it distrusts novelty, even though the taste for novelty has driven all arts at all periods. (Everett-Green 13 Oct 1990, C3)

After contemporary music came internationally famous performers, new approaches to programming, innovative interpreters, and performing artists "of depth." Everett-Green's list had a direct effect on music criticism in the Globe and Mail during the post-Kraglund years, as the newspaper abandoned its efforts to review every classical concert that took place in Toronto. By EverettGreen's estimate, such events in the city had multiplied to about three hundred per year, and he used his criteria to select which performances would be covered.

From his first contributions to the Globe and Mail, Everett-Green showed a willingness to discuss subjects other than music. He addressed a wide range of topics-from Barbie Dolls to Canada's multiculturalism policies-and in 1991 dance criticism was officially added to his duties at the newspaper. In 1994 he stopped writing about music altogether, becoming the newspaper's features writer (continuing, however, to select which classical music events would be covered); and also briefly served as a visual arts critic. In 1998 he took a sabbatical, returning the following year to again write about music. This time, however, he wrote on virtually all genres: from rock and rap to country and classical. ${ }^{14}$ Recalled Everett-Green:

When I came back, my editors asked me to write about music again. But it was my idea to become a critic who does almost any kind of music. No one said, "Here's your new job, and this is what you must do." (Everett-Green interview 2004)

He continued:

I'm interested in the social circumstances around music, and that interest can be followed through all kinds of music. Rock is not kids' music any more, and it hasn't been for some time. What I write about is mostly new music-hip-hop or a new opera.

14A possible precedent for Everett-Green's interest in virtually all styles of music may be found in the writings of the American critic John Rockwell, whose 1983 book All American Music is a collection of essays on avant-garde classical music, rock, jazz, and other genres. Everett-Green, however, denies any direct influence from Rockwell (Everett-Green interview 2004). 
In the post-Kraglund era, freelance writers also contributed significantly to the Globe and Mail's coverage of classical music. "Stringers" sometimes wrote about music in Kraglund's years as well, including Michael Schulman and Arthur Kaptainis (who later became music critic for the Montreal Gazette), but after 1987 they assumed a greater prominence. Such writers included Urjo Kareda, who wrote mostly about vocal music, and Elissa Poole. However, perhaps the most remarkable freelancer in this era was Tamara Bernstein.

Bernstein studied musicology at the University of Western Ontario before she began writing for the Globe and Mail in 1988, and her reviews often revealed a keen interest in period performance. In 1989 she chided pianist Konstanze Eickhorst for her interpretation of Schubert:

One wonders to what extent Eickhorst has explored period instruments; the Viennese fortepianos of Schubert's day, with their leather-covered hammers, have an innate speaking quality that can inspire the modern pianist; they can also suggest a transparent, more nuanced sound ideal, which contrasts with Eickhorst's often heavy-handed approach. (Bernstein 18 Mar 1989, C5)

In addition to her musicological interests, Bernstein also introduced feminist discourse into music criticism at the Globe and Mail. References to her feminist views appeared from time to time in her columns-never more pointedly than in a 1993 feature article on the Vienna Philharmonic Orchestra, which was about to make a Toronto appearance. Concerning the orchestra's policy of excluding female musicians, she observed:

What is most troubling in all this is that the Vienna Philharmonic gets away with it. Those who could put the screws to the orchestra-impresarios, corporate sponsors, concert-goers, record-buyers, even unionized stage hands—do not appear to have done so. (Bernstein 6 Feb 1993, C14)

She ended her article with a call for public pressure:

The issue of sexism in the classical music world is a complex, often subtle one that starts long before a woman arrives at a symphony audition. But there is nothing ambiguous about the Vienna Philharmonic's discrimination. If the VPO faced picket lines and played to empty halls for a few months, if recording companies refused to set up their microphones in front of it, and if corporations withdrew their sponsorship, I think we'd see some female faces in the band pretty quickly.

Backing her words with action, Bernstein participated in a public demonstration against the Vienna Philharmonic Orchestra, in front of Toronto's Roy Thomson Hall on the evening of the VPO's concert. Since then, the VPO has not returned to Toronto, although the orchestra now has one female member. Bernstein left the Globe and Mail in 1998 to become music critic for the National Post. 


\section{OVERVIEW}

Between 1936 and 2000, classical music criticism at the Globe and Mail underwent a profound transformation. In just six decades reviews went from encouraging, often flattering, commentaries to detailed critical discussions of performance, and also of the issues underlying performance. Feature articles went from promotional puffery to in-depth analyses, often with a probing or even confrontational tone. For many years, political, economic and cultural factors influencing music did not generally fall within the purview of Globe and Mail critics, but by the end of the century these subjects had assumed a prominent place in their writings.

Before 1952, the virtue, value and cultural "importance" of classical music were taken for granted, and its practitioners-especially Toronto's own musicians and musical institutions-were well supported by the Globe and Mail's critics. Classical music was portrayed as a precious but fragile cultural artifact, of benefit to society and intrinsically worthy of support from the newspaper. In the Kraglund era, while Bach, Beethoven and Brahms remained revered cultural icons, performing musicians and musical institutions were no longer immune from adverse criticism. The days of sheltering classical musicians at the Globe and Mail were over. To Kraglund, classical music in Toronto was a strong and abundant cultural force-so abundant that keen critical vigilance was needed to separate the wheat from the chaff. After 1987 classical music itself was subjected to criticism: its entrenched traditions, lack of modernity, aging White audience, financial precariousness, waning popularity, and its claims of "universality" and of superiority to all other musics were all-explicitly or implicitly-addressed. In this way the Globe and Mail entered largely uncharted territory and became increasingly detached from the traditions of North American classical music criticism.

It is interesting also to note the strong parallels between the changing styles of musical discourse at the Globe and Mail and within the profession of musicology. In the pre-war years, the newspaper's boosterism resembled musicology's advocacy of "music appreciation." After World War II, Kraglund's reviews, often unswervingly devoted to "the performance itself," paralleled musicology's mid-twentieth century focus on "the music itself." In recent decades, issues of socio-cultural context have risen to the fore in both musicological texts and the pages of the Globe and Mail. And throughout the twentieth century there was a general trend toward increased distance between critics and the musicians they wrote about-a complex issue in journalistic criticism that resonates in ongoing debates about ethnomusicological methods.

Today, it could be argued that coverage of classical music at the Globe and Mail is in decline, quantitatively speaking (see Figure 1): many musical organizations that were once regularly reviewed are now often passed over; and Everett-Green believes the newspaper will never again have a full-time critic dedicated solely to classical music (Everett-Green interview 2004). By tracing the trajectory of discourse in the Globe and Mail into the future, might we expect to see, some time in the twenty-first century, the newspaper de- 
nounce classical music as obsolete and irrelevant, washing its hands of the subject altogether? Perhaps-and if it did, it would not be the first newspaper in North America to do so. However, the future is not so easily predicted.

Figure 1:

Frequency of classical music articles* in the Globe and Mail, 1940-2000

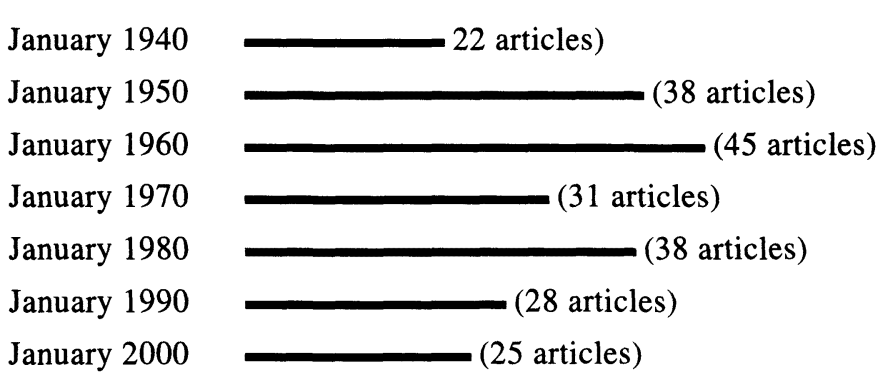

* Includes all performance reviews, record reviews, artist profiles, feature articles, concert listings, news items, editorials, opinion pieces, obituaries, and reviews of books about classical music, exceeding 100 words in length. (Does not include letters to the editor or paid advertising.)

At present, Globe and Mail no longer maintains the strong promotional agenda $v i s$-à-vis classical music that it once did: today, classical music must strive with popular musics, world musics, and other art forms for space in the newspaper's arts section. Yet the fact that thousands of Canadians continue to attend symphony and chamber concerts, recitals and operas, demonstrates that a demand for classical music continues to exist in this country. Aware of this constituency, the Globe and Mail remains willing to devote precious space to detailed reviews and sometimes lengthy feature articles on classical music, when its editors and writers feel that such attention is warranted. It seems likely that discussion of classical music, in some form, will continue at the newspaper well into the foreseeable future.

\section{REFERENCE LIST}

Beckwith, John. Interview, 8 Nov. 2004.

Cowle, Alan H. 1981. "Kraglund, John." In Encyclopedia of Music in Canada, eds. Helmut Kallmann, Gilles Potvin, and Kenneth Winters, 506. Toronto: University of Toronto Press.

Doyle, Richard J. 1990. Hurly-Burly: A Time at The Globe and Mail. Toronto: Macmillan.

Enright, Michael. 1980. “A Writer's Newspaper.” In Canadian Newspapers:

The Inside Story, ed. Walter Stewart. Edmonton: Hurtig.

Everett-Green, Robert. Interview, 26 Nov. 2004.

Globe and Mail (Toronto). 
Grant, Mark N. 1998. Masters of the Pen: A History of Classical Music

Criticism in America. Boston: Northeastern University Press.

Lipman, Samuel. 1984. "Harold Schonberg and His Times." In The House of Music: Art in an Era of Institutions, 216-227. Boston: David R. Godine. McCarthy, Pearl. 1956. Leo Smith. Toronto: University of Toronto Press. Schabas, Ezra, and Carl Morey. 2000. Opera Viva: Canadian Opera Company, the First Fifty Years. Toronto: Dundurn Press.

Wagner, Anton. 2003. "Mason, Lawrence." In Canadian Theatre Encyclopedia. www.canadiantheatre.com (accessed 1 Dec. 2004).

Warren, Richard S. 2002. Begins With the Oboe: A History of the Toronto Symphony Orchestra. Toronto: University of Toronto Press.

Winters, Kenneth. Interview, 22 Nov. 2004.

\section{Abstract}

This article is a study of developments in classical music criticism at the Toronto-based Globe and Mail newspaper from its inception in 1936 to the year 2000. Three distinct time-periods are identified, according to content, style and ideology: 1936-1952, a period of boosterism, when critics often saw it as their role to support Toronto's musicians and musical institutions; 1952-1987, when (during the lengthy tenure of critic John Kraglund) the newspaper took a more detached, non-partisan stance towards musicians and musical activities in the city; and 1987-2000, when critics began to address social, political, and economic issues governing classical music, and to question inherited cultural assumptions about the art form.

\section{Résumé}

Cet article étudie les développements de la critique musicale de la section de musique classique du journal Globe and Mail, de ses débuts en 1936 jusqu'à l'an 2000. On distingue trois périodes distinctes, en ce qui a trait au contenu, au style et à l'idéologie : 1936-1952, une période effervescente où les critiques considéraient de leur devoir de supporter les institutions musicales et les musiciens torontois; 1952-1987, époque où le journal a pris parti d'être plus détaché des musiciens et des activités musicales de la ville; 1987-2000, période où les critiques abordent les questions de nature sociale, politique et économique régissant la musique classique et remettent en question les a priori culturels de l'œuvre d'art. 